\title{
Analysis of the Fairness of Expenditure for Regional Apparatus Organizational Activities with an Activity Based Costing Approach
}

\author{
Halkadri Fitra $^{1 *}$, Henri Agustin ${ }^{2}$, Erly Mulyani ${ }^{3}$ \\ 1, 2,3 Universitas Negeri Padang, Padang, Indonesia \\ ${ }^{*}$ Corresponding author. Email: halkadri.feunp@gmail.com
}

\begin{abstract}
This study aims to determine the activity spending equation model and the fairness of the activity expenditure budget with an activity-based costing approach. The research object is the regional apparatus organization in West Pasaman Regency, West Sumatra Province with the research population being all activities budgeted by regional apparatus organizations in 2017 and 2018. The sample selection was carried out using purposive sampling technique so that 89 activities that met the criteria were obtained and then analyzed by the method descriptive quantitative using statistical formulas such as regression, standard deviation and minimum maximum limit. The results showed that: 1) the regression equation model for expenditure, namely $\mathrm{Y}=125,273,030.72+229,410.61 \mathrm{X}$, and 2) activities that have a budget in the fair category of $93.26 \%$ and $6.74 \%$ are not fair. Based on these results it is suggested that the regional government of West Pasaman Regency remains consistent in evaluating the budget for activities to be implemented so that the expenditure budget is in the fair category, while for the expenditure budget that is not reasonable it is necessary to repair the activities of the next period.
\end{abstract}

Keywords: Expenditure, Cost driver, Fairness, Standard

\section{INTRODUCTION}

Budget with work performance approach is a budget system based on performance indicators, performance or performance targets, analysis of spending standards, price unit standards, and minimum service standards [1]. Any funds issued by the Regional Government to implement programs and activities must be based on clear and measurable results and outputs. This is the main differentiator between the performance budget and the traditional budget that has been implemented before, which is more accountable for the planned input with the allocated input.

Article 298 of Law Number 23 Year 2014 [2] Concerning Regional Government paragraph 1 explains that regional expenditure is prioritized for funding mandatory government affairs related to basic services that are determined by minimum service standards and a good spending system. The existence of a good spending system will enable local governments to measure their financial performance and work performance. In order for the system to run optimally, several very decisive things need to be prepared, namely price standards, performance benchmarks and minimum service standards (SPM) which are determined based on statutory regulations [3]. Performance-Based Budget is a budget that connects the government budget with desired results (output and outcome), so that every rupiah issued can be accounted for benefits.
Performance-based budgeting is designed to create efficiency, effectiveness in the use of public expenditure budgets, with outputs and outcomes that clearly align with development priorities. Thus, all the budgets issued can be accounted for transparently to the wider community [14].

Information on expenditure components for an activity must be displayed accurately in a budget, so an assessment of its reasonableness is necessary. In order to assess the reasonableness of the input and the output produced, the role of Standard Expenditure Analysis (ASB) is needed. There are similar activities carried out by several agencies, but in providing funds for activity expenditures, there is the possibility of arousing jealousy from one agency towards other agencies due to the absence of an agreed equality model in the preparation of an activity expenditure. One model that can be used for shopping modeling is the principle of Activity Based Costing ( $\mathrm{ABC}$ ). The $\mathrm{ABC}$ approach will create a shopping process that emphasizes activity, so that if the activity of an activity is not much, it will not cost too much. As a new approach to calculating standard expenditure analysis (ASB) in the preparation of regional expenditure budgets, the $\mathrm{ABC}$ concept can provide an overview of costs that can be treated as variable, semi-variable and fixed costs.

West Pasaman Regency is one of the districts in West Sumatra Province which has 11 sub-districts and 19 
villages called nagari, with an area of $3,887.77 \mathrm{~km}^{2}$ and a population of 428,641 people (2017) with a distribution of 110 people / $\mathrm{km}$ [4]. This area was formed as a result of the division of Pasaman Regency based on Law Number 38 of 2003 dated 18 December 2003 [5], with the district capital at Simpang Ampek. West Pasaman's greatest potential lies in the plantation sector of oil palm, citrus, zalacca, rubber, coffee and cocoa [4]. In implementing government activities, the Regent is assisted by 43 regional apparatus organizations consisting of 18 regional agencies, 14 technical institutions and 11 sub-districts. As regional apparatus assisting the Regent's duties, regional apparatus organizations also carry out activities devised in order to achieve the regional vision, mission and goals. The preparation of activities is included in the regional revenue and expenditure budget with reference to performance-based budgets. The enactment of Law Number 32 of 2004 concerning Regional Government which is replaced by Law Number 23 of 2014 and Law Number 33 of 2004 concerning Financial Balance between the Central Government and Regional Governments has consequences for regions in the form of accountability for the allocation of funds owned in an efficient and effective way, especially in an effort to improve welfare and public services for the community [6].

Based on the above, the researcher feels interested in conducting research on the reasonableness of activity spending carried out by regional apparatus organizations in West Pasaman Regency by making the following problem formulations:

a. What is the activity spending model for regional apparatus organizations in West Pasaman Regency with the principle of activity-based costing?

b. How is the reasonableness of spending on activities of regional apparatus organizations in West Pasaman Regency by applying a spending model with the principle of activity-based costing?

The main criteria that underlie the implementation of public management today are economy, efficiency, effectiveness and transparency, and public accountability. The objectives desired by the community include accountability regarding the implementation of value for money, namely economy, (careful saving) in the procurement and allocation of resources, efficient (efficient) in the use of resources [7].

Several studies that have been conducted such as [8] on the Effect of Analysis of Expenditure Standards, Minimum Service Standards and Performance Indicators on Performance-Based Budgeting (Case Study on Regional Work Units of Pangkalpinang City) show that (1) Variable Analysis of Expenditure Standards has no effect performance-based budgeting in the Pangkalpinang City Government, (2) Minimum Service Standards Variable effect on performance-based budgeting in the Pangkalpinang City Government, and (3) Performance Indicator variables significantly influence performance-based budgeting in the Pangkalpinang City Government. Then [9] examined the Descriptive Study of the Standard Expenditure Analysis (Technical Assistance and Training) in North Mamuju Regency, showing the results that (1) ASB Model for technical assistance and training in North Mamuju Regency, divided into five activities, and (2) ASB Model what is formed should be used for the preparation, evaluation and control of the budget for assistance and training activities in North Mamuju District. Subsequent research by [10] with the topic of the Gresik Regency Expenditure Analysis Standards shows that basically all budgets used for personnel or human resource development activities are reasonable with the results of the $\mathrm{F}$ test with a significance level of 0.001 .

The Analysis of Expenditure Standards (ASB) encourages costing and budget allocation to each work unit activity to be more logical and encourages the achievement of efficiency continuously because of the comparison (benchmarking) of costs per unit of each output and obtaining best practices (best practices) in design activity [3]. In general, the meaning of Activity Based Costing System (ABC System) is a cost system that collects costs into activities that occur within the company and then charges these costs or activities to the product or service, and reports the cost of the activity and product or service to the management so that can then be used for planning, cost control, and decision making.

[11] defines Activity-Based Costing (ABC), as a system of allocating and reallocating costs to cost objects on the basis of activities that cause costs. This ABC system is based on the premise that activity causes costs and activity costs must be allocated to cost objects on the basis of these activities costs are consumed. This ABC system traces the cost to the product as the basis for the activities used to produce the product. This is also in accordance with the opinion of [15] which states that Activity-Based Costing (ABC) is a system which recognizes that the implementation of activities leads to consumption of resources which are recorded as costs, or in other words that $\mathrm{ABC}$ is a cost calculation approach. based on transactions. Based on these results, the objectives of this study are:

a. to find out the spending model for the activities of regional apparatus organizations in West Pasaman Regency with activity-based costing

b. to find out the reasonableness of spending for regional apparatus organizational activities by applying the activity-based costing model.

According to the [16] the benefits of ABC include:

a. Help identify inefficiencies that occur in the production process, either per-department, per- 
product, or per-activity. This is possible with the $\mathrm{ABC}$ process, considering that the application of the $\mathrm{ABC}$ system must be done through an analysis of activities that occur throughout the company, so that the company or managers can clearly know the costs that should be incurred (value added costs) and costs that should not be incurred. (nonvalue added costs).

b. Helping decision making better because the calculation of costs on a cost object becomes more accurate because the company is more familiar with the behavior of factory overhead costs and can help allocate resources owned by the company to more profitable cost objects.

c. Help control costs (especially factory overhead costs) to the individual and departmental levels. This can be done considering that $\mathrm{ABC}$ focuses more on the cost per unit rather than the total cost.

\section{METHODS}

\subsection{Research Objects and Locations}

The research object is the regional apparatus organization in West Pasaman Regency. The study population included all activities contained in the Budget Implementation Documents for West Pasaman Regency 2017 and 2018 Fiscal Years. The research sample was selected using purposive sampling method with the following criteria:

a. Activities carried out by the Service, Office and Agency other than the District.

b. The activities carried out can be traced to the cost driver in person days.

c. Activities undertaken are not activities for capital expenditure
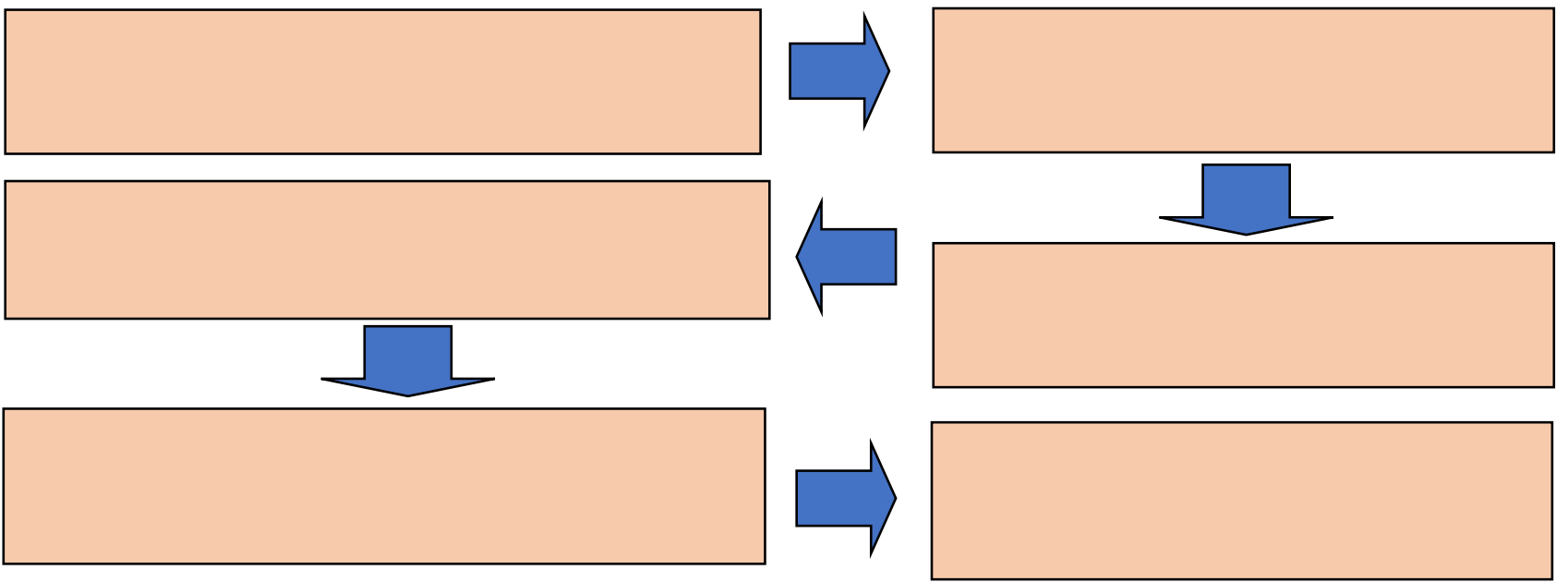

This study uses quantitative data in the form of numeric data, such as the amount of expenditure, the number of participants, the number of activity days, the unit price, and the volume that comes from the internal place of the study. The type of data used is secondary data, namely documentation data and official archives, such as Revised Budget Implementation Documents (DPA-P), Price Unit Standards, Regent Regulations and the like, which are sourced from the Regional Finance Agency of West Pasaman Regency.

\subsection{Research Steps}

The research steps carried out are as follows:

\subsection{Data Analysis}

Data analysis was carried out by following the steps below:

a. Collecting secondary data in the form of existing local government activities in the current year in the form of DPA Changes and also secondary data in the form of unit price standards.

b. Checking the conformity of the existing unit price in the Amendment DPA with the regent's regulation on unit price standards. 
c. Identify each type of activity regarding its output and cost drivers.

d. Determine what activities are necessary and a standard expenditure analysis will be made.

e. Perform initial grouping of each activity that has the same output and cost driver into one ASB group, then name the ASB group.

f. Conduct discussions on the initial groupings that have been made of activities, outputs and cost drivers of an activity. Then agreed to improve the ASB groups.

g. Create a simple regression model for each agreed ASB group.

h. $\quad$ Calculate the minimum and maximum value of expenditure from the simple regression model of each ASB group. To see the minimum and maximum value of expenditure, the reliability of the estimated line equation is calculated, then the standard deviation of estimates can be used. Its use in ASB modeling is to determine the maximum and minimum values. The formula used is:

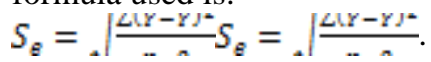

(1)

$\mathrm{Se}=$ The standard error in the estimates

$(Y-\hat{Y})^{-}(Y-\hat{Y})^{-}=$squared error

$\mathrm{n}=$ amount of data

Based on the Equation (1), the estimated minimum value for shopping can be determined using the formula: $T B \min =\hat{Y}-t_{\mathrm{p}} . S_{e} T B \min =\hat{Y}-t_{\mathrm{g}} . S_{e}$

Tbmin $=$ Estimated minimum activity expenditure

$\overline{\mathrm{Y}}=$ average of activity expenditure

$\mathrm{t}_{\mathrm{p}}=$ the value obtained from table $\mathrm{t}$ with $\mathrm{n}-2$ degrees of freedom

$\mathrm{S}_{\mathrm{e}}=$ The standard error in the estimates

As for the estimated maximum value of expenditure with the formula:

$T B \max =\hat{Y}+t_{\mathrm{g} .} S_{e} T B \max =\hat{Y}+t_{\mathrm{g} .} S_{e} \ldots \ldots \ldots \ldots \ldots$ (3)

Tbmax = Estimated maximum activity expenditure

$\overline{\mathrm{Y}}=$ average of activity expenditure

$t_{p}=$ The value obtained from table $t$ with $n-2$ degrees of

$\mathrm{S}_{\mathrm{e}}=$ The standard error in the estimates

After we know the estimated minimum expenditure and the estimated maximum expenditure, the conclusions obtained are:

1) If the activity budget value is below the maximum estimated value and above the minimum estimated value, then the activity budget is said to be reasonable.

2) If the activity budget value is above the maximum estimated value or below the minimum estimated value, then the activity budget is said to be unreasonable.

i. Calculating the percentage of expenditure allocation for each expenditure object (activity) in one ASB group, both the average expenditure allocation, the minimum expenditure allocation and the maximum expenditure allocation.

The basic assumptions used in the preparation of ASB are as follows:

a. The size of the budget is influenced by workload. This assumption conveys that the preparation of ASB must be based on the principle of a performance-based budget, that is, the greater the performance produced, the greater the budget.

b. Standards are instruments that are created so that there is uniformity of practice in the future.

c. Shopping that is below the maximum limit value and above the minimum threshold value is called fair shopping.

d. The approach to drafting ASB is a democratic (not authoritarian) approach. What is meant by democracy is, all the aspirations of SKPD / OPD are heard and considered in the same capacity.

\section{RESULTS AND DISCUSSION 3.1. Results}

The results of the study are as follows:

a. Equation model

Based on data processing on 89 activities used as research samples in regional apparatus organizations including offices, offices, agencies and secretariats other than sub-district offices in 2017 and 2018, a standard analysis model for activity expenditures was obtained in regional apparatus organizations of West Pasaman Regency in 2017 and 2018 that is:

$$
Y=125,273,030.72+229,410.61 X
$$

Based on the equation formula obtained, it is known that the value of a as fixed expenditure is IDR $125,273,030.72$ and the value of $b$ is IDR $229,410.61$ for variable expenditures for each value of $1 \mathrm{x}$ in this case is person days $(\mathrm{OH})$. For every one increase in the $\mathrm{X}$ value unit, the total expenditure will increase by IDR $229,410.61$. This indicates that the total expenditure will increase if there is an increase in activities indicated by a value of $X$, so that the total value of regional activity expenditure is influenced by activities carried out by the offices, agencies, secretariat and offices.

b. Fairness of Activity Expenditures with the Application of the Activity Based Costing Model Based on the regression equation obtained, an assessment of the reasonableness of the 89 activities used as a sample was carried out according to the data analysis steps, the results are as follows: 
Table 1. Regional Expenditure Categories for Regional Apparatus Organizational Activities

\begin{tabular}{llcc}
\hline No & Description & Number of Activities & Percentage \\
\hline 1 & Activities that fall under the category of fair activity expenditure & 83 & 93,26 \\
\hline 2 & $\begin{array}{l}\text { Activities that fall under the category of unfair activity } \\
\text { expenditure }\end{array}$ & 6 & 6,74 \\
\hline
\end{tabular}

Amount
Based on Table 1, it is known that the number of
activities carried out by the Regional Apparatus
Organization using expenditure in the fair category is 83
activities with a percentage of $93.26 \%$. There are 83
regional expenditure activities that fall into the fair

category because the total activity expenditure is between the upper and lower limits of total expenditure calculated based on standard expenditure analysis.

Furthermore, there are 6 activities that are in the inappropriate category, namely as follows:

Table 2. Total Expenditures for Activities that are in the Unfair Category

\begin{tabular}{|c|c|c|c|c|c|}
\hline No & Activities & $\begin{array}{c}\text { Name of Regional } \\
\text { Apparatus } \\
\text { Organization }\end{array}$ & $\begin{array}{l}\text { Budget } \\
\text { (IDR) }\end{array}$ & $\begin{array}{c}\text { Minimum Limit of } \\
\text { Activity } \\
\text { Expenditure Based } \\
\text { on Expenditure } \\
\text { Standard Analysis } \\
\text { Calculation (IDR) }\end{array}$ & $\begin{array}{c}\text { Maximum Limit of } \\
\text { Activity } \\
\text { Expenditures based } \\
\text { on Standard } \\
\text { Expenditure } \\
\text { Analysis Calculation } \\
\text { (IDR) }\end{array}$ \\
\hline 1 & $\begin{array}{l}\text { Technical guidance on } \\
\text { the implementation of } \\
\text { laws and regulations } \\
(2017)\end{array}$ & $\begin{array}{l}\text { The Secretariat of } \\
\text { the Regional } \\
\text { People's } \\
\text { Representative } \\
\text { Council }\end{array}$ & $400,300,500$ & $(117,661,611.71)$ & $372,795,885.32$ \\
\hline 2 & $\begin{array}{l}\text { Publication / } \\
\text { socialization of policy } \\
\text { products of DPRD } \\
\text { Leaders and Members } \\
\text { and DPRD activities } \\
(2017)\end{array}$ & $\begin{array}{l}\text { The Secretariat of } \\
\text { the Regional } \\
\text { People's } \\
\text { Representative } \\
\text { Council }\end{array}$ & $594,900,000$ & $(136,705,340.61)$ & $433,133,523.67$ \\
\hline 3 & $\begin{array}{l}\text { Technical guidance on } \\
\text { the implementation of } \\
\text { laws and regulations } \\
\text { (2017) }\end{array}$ & $\begin{array}{l}\text { Regional public } \\
\text { hospital }\end{array}$ & $635,471,000$ & $(195,529,303.21)$ & $619,509,784.32$ \\
\hline 4 & $\begin{array}{l}\text { Technical guidance on } \\
\text { the implementation of } \\
\text { laws and regulations } \\
\text { (2017) }\end{array}$ & BPKD & $422,344,000$ & $(125,067,506.29)$ & $396,260,522.46$ \\
\hline 5 & $\begin{array}{l}\text { Technical guidance on } \\
\text { the implementation of } \\
\text { laws and regulations } \\
\text { (2017) }\end{array}$ & $\begin{array}{l}\text { Department of } \\
\text { Public Works and } \\
\text { Spatial Planning }\end{array}$ & $404,692,000$ & $(118,719,596.65)$ & $376,147,976.34$ \\
\hline 6 & $\begin{array}{l}\text { Publication / } \\
\text { socialization of policy } \\
\text { products of the DPRD } \\
\text { Leaders and Members } \\
\text { and the activities of the } \\
\text { District DPRD. West } \\
\text { Pasaman (2018) }\end{array}$ & $\begin{array}{l}\text { The Secretariat of } \\
\text { the Regional } \\
\text { People's } \\
\text { Representative } \\
\text { Council }\end{array}$ & $704,300,000$ & $(136,705 ., 340.61)$ & $433,133,523.67$ \\
\hline
\end{tabular}

Based on Table 2, we can see that there are 6 activities with a percentage of $6.74 \%$ which are in the inappropriate category. Activities that are in the unnatural category are caused because the total budget for activities is above the maximum limit of total expenditure calculated based on the Standard Expenditure Analysis.

\subsection{Discussion}

The equation of the regression model $\mathrm{Y}=$ $125,273,030.72+229,410.61 \mathrm{X}$ means that the activities carried out have fixed costs of IDR 125,273,030.72 and have variable costs that will increase by IDR 229,410.61 for each activity. Based on Table 1, it can be seen that all activities carried out by regional apparatus organizations other than sub-districts in West Pasaman 
Regency in the 2017 and 2018 periods are in the fair category of $93.26 \%$. Meanwhile, there were 6 activities categorized as unnatural spending with a percentage of $6.74 \%$.

Activities that have an unreasonable amount of activity expenditure can be caused by a large number of expenditure items and a large amount of activity expenditure. Therefore, agencies, agencies and offices related to activities that have unreasonable activity expenditures should evaluate the types of expenditure object details that are used in calculating the activity expenditure budget. In addition, an evaluation of the total activity expenditure can also be carried out by taking into account the total activity expenditure based on the calculation of standard expenditure analysis, so that in the end the total activity expenditure can be in the fair category.

\section{CONCLUSIONS}

a. The standard analysis model for activity expenditures in the West Pasaman district blood device organization is $\mathrm{Y}=125,273,030.72+229,410.61 \mathrm{X}$

b. The fairness of expenditure on the activities of regional apparatus organizations in West Pasaman Regency by applying a spending model with the principle of activity-based costing based on the calculation obtained $93.26 \%$ in the fair category and $6.74 \%$ in the improper category.

\section{ACKNOWLEDGMENTS}

The author would like to thank the Chancellor of Padang State University, the Dean of the Faculty of Economics, the West Pasaman Regency Government, and all those who helped in this research activity from start to finish.

\section{REFERENCES}

[1] Pemerintah Indonesia. Peraturan Menteri Dalam Negeri Nomor 13 Tahun 2006 Tentang Pedoman Pengelolaan Keuangan Daerah. Jakarta. 2006

[2] Pemerintah Indonesia. Undang-Undang Nomor 23 Tahun 2014 Tentang Pemerintah Daerah. Lembaran Negara Republik Indonesia Tahun 2014 Nomor 244. Jakarta 2014

[3] Kawedar, Warsito, et.al. Akuntansi Sektor Publik: Pendekatan Penganggaran Daerah dan Akuntansi Keuangan Daerah. Semarang: Universitas Diponogoro. 2008

[4] Badan Pusat Statistik. Kabupaten Pasaman Barat
Dalam Angka. BPS Kabupaten Pasaman Barat. 2019

[5] Pemerintah Indonesia. Undang-Undang Republik Indonesia Nomor 38 Tahun 2003 Tentang Pembentukan Kabupaten Dharmasraya, Kabupaten Solok Selatan, Dan Kabupaten Pasaman Barat Di Provinsi Sumatera Barat. Lembaran Negara Republik Indonesia Tahun 2003 Nomor 153. Jakarta. 2003.

[6]. Pemerintah Indonesia. Undang-undang Nomor 33 Tahun 2004 Tentang Perimbangan Keuangan Antara Pemerintah Pusat dan Pemerintahan Daerah. Lembaran Negara Republik Indonesia Tahun 2004 Nomor 126. 2004.

[7] Ulum, Ihyaul. Audit Sektor Publik: Suatu Pengantar. Jakarta. Penerbit PT Bumi Aksara. 2009.

[8] Anggita, Wenni. Pengaruh Analisis Standar Belanja, Standar Pelayanan Minimal dan Indikator Kinerja terhadap Penyusunan Anggaran Berbasis Kinerja (Studi Kasus Pada Satuan Kerja Perangkat Daerah Kota Pangkalpinang). Journal of Accounting and Finance Vol. 2 No. 01 2017. 2017

[9] Amir, Andi Mattulada. Kajian Deskriptif Analisa Standar Belanja (Asistensi dan Pelatihan Teknis) Kabupaten Mamuju Utara. Jurnal Sinar Manajemen Vol 5, No 1, 2018 E-ISSN 2598-398X P-ISSN 2337- 8743. 2018.

[10] Mardiana, Lilik \& Sukamto. Standar Analisa Belanja Kabupaten Gresik. Equilibrium, Volume 12, Nomor 2, Oktober 2014, hlm. 172-192. 2014

[11] Morse, Wayne J., James R. Davis., dan Al. L. Hartgraves. Management Accounting. 3rd Edition. Addision-Wesley Publishing Company. 1995.

[12] Sukmadinata, Nana Syaodih. Metode penelitian Pendidikan. Bandung: Remaja Rosdakarya. 2009.

[13] Kerlinger, Fred N. \& Howard B. Lee. Foundations of Behavioral Research. 4 th Edition. Florida: Harcourt Inc. 2000.

[14] Taufiq, Kurrohman. Evaluasi Penganggaran Berbasis Kinerja Melalui Kinerja Keuangan yang Berbasis Value For Money di Kabupaten/Kota Jawa Timur. Universitas Jember. National Scientifik Journal of Unnes. Vol.5 No.1. 2013.

[15] Rayburn, Gayle L. Akuntansi Biaya dengan Menggunakn Pendekatan Manajemen Biaya. Jakarta: Erlangga. 1999

[16] Dunia, Firdaus Ahmad, dan Wasilah. Akuntansi Biaya. Jakarta: Salemba Empat. 2018. 